\title{
Natranaerobius thermophilus gen. nov., sp. nov., a halophilic, alkalithermophilic bacterium from soda lakes of the Wadi An Natrun, Egypt, and proposal of Natranaerobiaceae fam. nov. and Natranaerobiales ord. nov.
}

Correspondence Juergen Wiegel jwiegel@uga.edu

\author{
Noha M. Mesbah, ${ }^{1}$ David B. Hedrick, ${ }^{2}$ Aaron D. Peacock, ${ }^{2}$ \\ Manfred Rohde ${ }^{3}$ and Juergen Wiegel ${ }^{1}$ \\ ${ }^{1}$ Department of Microbiology, University of Georgia, Athens, GA 30602, USA \\ ${ }^{2}$ University of Tennessee, Knoxville, TN 37932, USA \\ ${ }^{3}$ Department of Microbial Pathogenicity, Helmholtz Center for Infection, Research, Inhoffenstrasse \\ 7, D-38124 Braunschweig, Germany
}

\begin{abstract}
Novel halophilic, alkalithermophilic, Gram-type-positive bacterial strains were isolated from sediment of alkaline, hypersaline lakes of the Wadi An Natrun, Egypt. Cells of strain JW/NM-WN-LF ${ }^{\top}$ were rod-shaped, non-spore-forming and non-motile. Strain JW/NM-WN-LF ${ }^{\top}$ grew (at $\mathrm{pH}^{55^{\circ} \mathrm{C}}$ 9.5) between 35 and $56{ }^{\circ} \mathrm{C}$, with an optimum at $53{ }^{\circ} \mathrm{C}$. The $\mathrm{pH}^{55^{\circ} \mathrm{C}}$ range for growth was 8.3-10.6, with an optimum at $\mathrm{pH}^{55^{\circ} \mathrm{C}} 9.5$ and no growth at $\mathrm{pH}^{55^{\circ} \mathrm{C}} 8.2$ or below, or at $\mathrm{pH}^{55^{\circ} \mathrm{C}} 10.8$ or above. At the optimum $\mathrm{pH}$ and temperature, the strain grew in the $\mathrm{Na}^{+}$ range of 3.1-4.9 $\mathrm{M}(1.5-3.3 \mathrm{M}$ added $\mathrm{NaCl})$ and optimally between 3.3 and $3.9 \mathrm{M} \mathrm{Na}^{+}$ (1.7-2.3 $\mathrm{M}$ added $\mathrm{NaCl}$ ). Strain JW/NM-WN-LF ${ }^{\top}$ utilized fructose, cellobiose, ribose, trehalose, trimethylamine, pyruvate, Casamino acids, acetate, xylose and peptone as carbon and energy sources. Fumarate $(20 \mathrm{mM}), \mathrm{S}_{2} \mathrm{O}_{3}^{2-}(20 \mathrm{mM}), \mathrm{NO}_{3}^{-}(20 \mathrm{mM})$ and iron(III) citrate $(20 \mathrm{mM})$ were utilized as electron acceptors. During growth on sucrose, the isolate produced acetate and formate as major fermentation products. Main cellular fatty acids were iso-branched $15: 0,117: 0$ dimethylacetal and 16:0 dimethylacetal. The $\mathrm{G}+\mathrm{C}$ content of genomic DNA was $40.4 \mathrm{~mol} \%$ (HPLC). On the basis of genotypic and phenotypic characteristics, it is proposed that strain JW/NM-WN-LF ${ }^{\top}$ represents a novel genus and species, Natranaerobius thermophilus gen. nov., sp. nov. The type strain is JW/NM-WN-LF ${ }^{\top}\left(=\mathrm{DSM} 18059^{\top}=\mathrm{ATCC}^{\mathrm{BAA}}-1301^{\top}\right)$. Based on $16 \mathrm{~S}$ rRNA gene sequence analysis, the strain forms a novel lineage within the class 'Clostridia' and clusters with uncultivated bacteria and unidentified strains retrieved from alkaline, hypersaline environments. The phylogenetic data suggest that the lineage represents a novel family, Natranaerobiaceae fam. nov., and order, Natranaerobiales ord. nov.
\end{abstract}

Extremophiles are micro-organisms that are well adapted to one or two extreme environmental conditions. Halophilic alkalithermophiles are a novel physiological group that require high salt concentrations, alkaline $\mathrm{pH}$ values and elevated temperatures for growth. Halophilic

Abbreviations: DMA, dimethylacetal; PLFA, phospholipid fatty acid.

The GenBank/EMBL/DDBJ accession number for the 16S rRNA gene sequence of strain JW/NM-WN-LF' is DQ417202.

A supplementary table showing the PLFA composition of strain JW/NM$\mathrm{WN}-\mathrm{LF}^{\top}$ and supplementary figures showing the dependence of growth of strain JW/NM-WN-LF ${ }^{\top}$ on temperature and medium $\mathrm{pH}$ and a FitchMargoliash tree based on 16S rRNA gene sequences are available with the online version of this paper. alkalithermophiles must possess special adaptive mechanisms for survival under these three extreme conditions. As a result of their unique and extreme growth conditions, halophilic alkalithermophiles are of considerable commercial and biotechnological significance. Halophilic alkalithermophiles are also of evolutionary significance, as they represent model organisms for evaluating theories on the origin of life. These include the hypothesis that life evolved in shallow, heated saline and alkaline pools (Baross, 1998; Zavarzin, 1993). We describe in this report the characterization of, to our knowledge, the first true anaerobic, halophilic alkalithermophile isolated from sediments of the solar-heated, alkaline, hypersaline soda lakes of the Wadi An Natrun, Egypt [criteria for defining halophiles, 
alkaliphiles and thermophiles have been described by Oren (2000) and Wiegel (1998a)]. On the basis of the physiological and phylogenetic evidence presented, we propose a novel genus, Natranaerobius gen. nov., to accommodate this micro-organism. Further, the order Natranaerobiales ord. nov., consisting of the family Natranaerobiaceae fam. nov., is proposed to encompass Natranaerobius gen. nov.

\section{Isolation and cultivation of strain JW/NM-WN-LF ${ }^{\mathbf{T}}$}

Strain JW/NM-WN-LF ${ }^{\mathrm{T}}$ was isolated from a mixed watersediment sample collected from the sediment of Lake Fazda, Wadi An Natrun, Egypt, during May 2005. At the time of collection, the lake water had a salinity of $4.7 \mathrm{M}$ and $\mathrm{pH}^{25}{ }^{\circ} \mathrm{C} 9.8$. For initiating enrichment cultures, $5 \mathrm{~g}$ soil was inoculated into $80 \mathrm{ml}$ carbonate-buffered medium consisting of $\left(\mathrm{g} \mathrm{l}^{-1}\right): \mathrm{KH}_{2} \mathrm{PO}_{4}, 0.2 ; \mathrm{MgCl}_{2}, 0.1 ; \mathrm{KCl}, 0.2$; $\mathrm{NH}_{4} \mathrm{Cl}, \quad 0.5 ; \mathrm{NaCl}, \quad 100 ; \mathrm{Na}_{2} \mathrm{CO}_{3}, 68 ; \mathrm{NaHCO}_{3}, 38 ;$ cysteine. $\mathrm{HCl}, 0.7$; yeast extract, 5 ; tryptone, 5; sucrose, 5; and trace element solution, $1 \mathrm{ml}$ (Kevbrin \& Zavarzin, 1992); vitamin solution, $10 \mathrm{ml}$ (Wolin et al., 1963). The $\mathrm{pH}^{55}{ }^{\circ} \mathrm{C}$ was adjusted to 9.5 with anaerobic $5 \mathrm{M} \mathrm{HCl}$. The enrichment cultures became turbid after $48 \mathrm{~h}$ growth at $55{ }^{\circ} \mathrm{C}$. Pure cultures were obtained in dilution rows in agar ( $1 \%$, w/v) shake-roll tubes (Ljungdahl \& Wiegel, 1986). To ensure that colonies were derived from a single cell, the isolate was purified by four successive rounds of singlecolony isolation. The isolates were maintained in the carbonate-buffered medium at $\mathrm{pH}^{55{ }^{\circ} \mathrm{C}} 9.5$ and $55{ }^{\circ} \mathrm{C}$ under anaerobic conditions $\left(\begin{array}{lll}100 \% & \mathrm{~N}_{2}\end{array}\right)$ by using a modified Hungate technique (Ljungdahl \& Wiegel, 1986).

\section{Colony and cell morphology}

Colonies of strain JW/NM-WN- $\mathrm{LF}^{\mathrm{T}}$ appeared in agar shake-roll tubes after 3-4 days and were $1-2 \mathrm{~mm}$ in diameter, circular to irregularly shaped and opaque. Cell morphology was observed via light microscopy (Olympus VANOX phase-contrast microscope) and electron microscopy. Cells in liquid culture in the exponential-growth phase were straight to curved rods, $0.2-0.4 \mu \mathrm{m}$ in diameter and $3-5 \mu \mathrm{m}$ in length. Cells either were single or formed chains. No active motility was observed under phasecontrast microscopy; accordingly, flagella were absent in negatively stained samples ( $2 \%$ uranyl acetate). Cells exhibited a rod-like appearance with variable length, as shown by field emission scanning electron microscopy (Fig. 1a; taken with a Zeiss DSM982 Gemini). Ultrathin sections exhibit a Gram-type-positive cell wall and no endospores were observed either with a Zeiss EM910 (Fig. 1b) or by light microscopy after heat treatment $\left(10 \mathrm{~min}\right.$ at $\left.80{ }^{\circ} \mathrm{C}\right)$ (Fig. 1). Cells stained Gram-positive in both the early exponential- and stationary-growth phases (Doetsch, 1981).

\section{Cultural and physiological characteristics}

The optimal conditions for growth of strain JW/NM-WN$\mathrm{LF}^{\mathrm{T}}$ were tested in carbonate-buffered medium with $0.3 \%$ yeast extract and tryptone, $640 \mathrm{mM} \mathrm{Na} \mathrm{CO}_{3}$ and $320 \mathrm{mM}$ $\mathrm{NaHCO}_{3}$ (before $\mathrm{pH}$ adjustment, yielding a base $\mathrm{Na}^{+}$ concentration of 1.6 M). By using a temperature-gradient incubator (Scientific Industries, Inc.), the temperature range for growth (at $\mathrm{pH}^{55}{ }^{\circ} \mathrm{C}$ 9.5) was $35-56{ }^{\circ} \mathrm{C}$ with an optimum at $53{ }^{\circ} \mathrm{C}$, and no growth was observed at $34{ }^{\circ} \mathrm{C}$ or below, or at $57{ }^{\circ} \mathrm{C}$ or above after 2 weeks.

The growth-temperature profile revealed a broken Arrhenius plot with two peaks and an intermediate plateau [see Supplementary Fig. S1(a), available in IJSEM Online]. The initial peak in growth rate occurred at $37^{\circ} \mathrm{C}$ (doubling time, $6 \mathrm{~h}$ ); the second, and larger, peak in growth occurred at $53{ }^{\circ} \mathrm{C}$ (doubling time, $3.2 \mathrm{~h}$ ). Such a pattern has been observed with other thermophiles (Wiegel, 1990, 1998b). Dilution to extinction, microscopy and 16S rRNA gene sequence analysis all confirmed that the isolate was pure and was not contaminated with another mesophilic or thermotolerant micro-organism that could have caused the initial growth peak at $37^{\circ} \mathrm{C}$.

The $\mathrm{pH}$ range for growth was determined at $55{ }^{\circ} \mathrm{C}$ in the above-mentioned carbonate-buffered medium. All $\mathrm{pH}$ measurements were performed as described previously (Mesbah \& Wiegel, 2006) with a microelectrode (Accumet
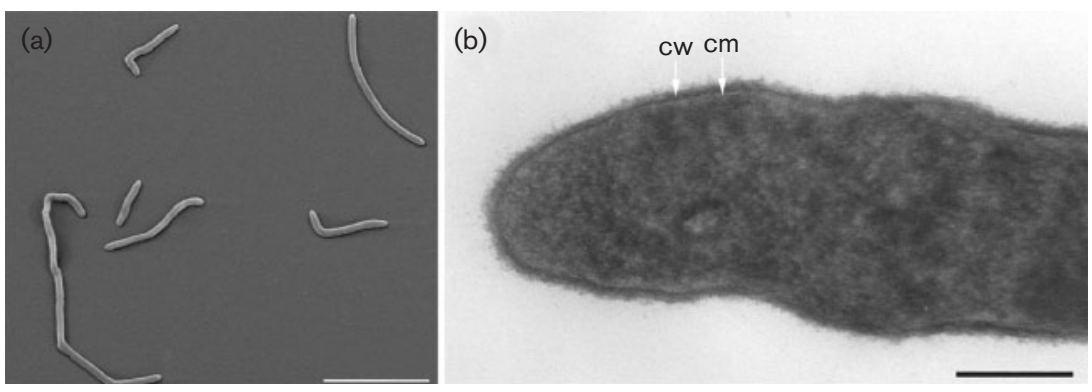

Fig. 1. Electron microscopic images of strain JW/NM-WN-LF' ${ }^{\top}$. (a) Field emission scanning electron micrograph of aldehyde-fixed, acetone-dehydrated and critical point-dried cells of strain JW/NM-WN-LF', revealing a rod-like appearance with variable length of single cells. Bar, $5 \mu \mathrm{m}$. (b) Ultrathin section (embedded in LR White and counterstained with uranyl acetate), exhibiting the Gram-positive-like cell structure (cm, cell membrane; cw, cell wall); furthermore, no endospores were detectable within the cytoplasm. Bar, $0.25 \mu \mathrm{m}$. 
combination microelectrode with calomel reference; ColeParmer), calibrated at $55{ }^{\circ} \mathrm{C}$ with $\mathrm{pH}$ standards preheated to the same temperature. The $\mathrm{pH}$ of the medium was adjusted by addition of sterile, anaerobic $\mathrm{HCl}$ or $\mathrm{Na}_{2} \mathrm{CO}_{3}$. The $\mathrm{pH}^{55^{\circ} \mathrm{C}}$ range for growth was 8.3-10.6, with an optimum at $\mathrm{pH}^{55^{\circ} \mathrm{C}}$ 9.5. There was no growth at $\mathrm{pH}^{55^{\circ} \mathrm{C}} 8.2$ or below, or at $\mathrm{pH}^{55^{\circ} \mathrm{C}} 10.8$ or above [Supplementary Fig. S1(b)].

The salinity range for growth was determined in carbonatebuffered medium at $\mathrm{pH}^{55}{ }^{\circ} \mathrm{C}$ 9.5. Strain JW/NM-WN-LF grew over total $\mathrm{Na}^{+}$concentrations (which includes 1.53.3 $\mathrm{M}$ added $\mathrm{NaCl}$ ) of 3.1-4.9 $\mathrm{M}$ [corresponding to 18.0 $28.5 \%(\mathrm{w} / \mathrm{v}) \mathrm{NaCl}$. No growth occurred when the total $\mathrm{Na}^{+}$ concentration was below 3.0 M. Optimal growth occurred at $\mathrm{Na}^{+}$concentrations between 3.3 and 3.9 M. Maximum $\mathrm{Na}^{+}$ tolerance of strain JW/NM-WN-LF ${ }^{\mathrm{T}}$ was not increased or decreased by addition of $500 \mathrm{mM} \mathrm{KCl}$ to the growth medium. Strain JW/NM-WN-LF ${ }^{\mathrm{T}}$ did not grow when equimolar amounts of $\mathrm{K}_{2} \mathrm{CO}_{3}$ and $\mathrm{KHCO}_{3}$ were substituted for $\mathrm{Na}_{2} \mathrm{CO}_{3}$ and $\mathrm{NaHCO}_{3}$, even in the presence of 1.7-3.1 M $\mathrm{NaCl}$. The doubling time at the optimal conditions, i.e. $3.5 \mathrm{M} \mathrm{Na}^{+}, \mathrm{pH}^{55{ }^{\circ} \mathrm{C}} 9.5$ and $53{ }^{\circ} \mathrm{C}$, was $3.5 \mathrm{~h}$.

For substrate-utilization tests, cultures were incubated for up to 5 days and growth was judged positive if, in the third successive transfer, the $\mathrm{OD}_{600}$ of the culture was twice that of a control culture incubated with only $0.2 \%$ yeast extract and tryptone. Utilization of possible substrates $(0.5 \%, \mathrm{w} / \mathrm{v})$ was tested in the presence of $0.2 \%$ yeast extract and tryptone. Strain JW/NM-WN-LF ${ }^{\mathrm{T}}$ used fructose, cellobiose, ribose, trehalose, trimethylamine, pyruvate, Casamino acids, acetate, xylose and peptone as carbon and energy sources. No growth was observed with glucose, mannose, formate, glycine betaine, ethanol, n-propanol or ribitol as carbon or energy sources. The use of electron acceptors was determined by measuring growth (increase in $\mathrm{OD}_{600}$ ), production of sulfide, ammonium and nitrate, and colour change. In the presence of $0.2 \%$ yeast extract, strain JW/NM-WN-LF ${ }^{\mathrm{T}}$ utilized the following as electron acceptors: fumarate $(20 \mathrm{mM}), \mathrm{S}_{2} \mathrm{O}_{3}^{2-}(20 \mathrm{mM}), \mathrm{NO}_{3}^{-}$ $(20 \mathrm{mM})$ and iron(III) citrate $[20 \mathrm{mM}$, determined by $A_{562}$ of $\mathrm{Fe}(\mathrm{II})$-ferrozine complex (Stookey, 1970)]. None of the following electron acceptors was utilized: $\mathrm{SO}_{4}^{2-}$ $(20 \mathrm{mM}), \mathrm{SO}_{3}^{2-}(20 \mathrm{mM})$ or $\mathrm{MnO}_{2}(10 \mathrm{mM})$. The main organic fermentation products from $20 \mathrm{mM}$ sucrose were acetate $(17 \mathrm{mM})$ and formate $(10 \mathrm{mM})$, and minor amounts of lactate $(2.5 \mathrm{mM})$ were also produced.

Strain JW/NM-WN-LF ${ }^{\mathrm{T}}$ was negative for catalase and oxidase, gelatin liquefaction and casein degradation. Strain JW/NM-WN-LF ${ }^{\mathrm{T}}$ was obligately anaerobic. Negative results were obtained in API ZYM enzyme assay (bioMérieux) for alkaline phosphatase, esterase C-4, esterase lipase, leucine arylamidase, valine arylamidase and cystine arylamidase, trypsin, $\alpha$-chymotrypsin, acid phosphatase, naphthol- $\alpha, \beta-$ phosphohydrolase, $\alpha$ - and $\beta$-galactosidase, $\alpha$ - and $\beta$ glucosidase, $\beta$-glucouronidase, $\alpha$-mannosidase, $\alpha$-fucosidase and $N$-acetyl- $\beta$-glucosaminidase.

\section{Chemotaxonomic characteristics}

Attempts to purify peptidoglycan from cells of strain JW/ $\mathrm{NM}-\mathrm{WN}-\mathrm{LF}^{\mathrm{T}}$ failed, and no isomer of diaminopimelic acid was detected in the strain. It was concluded that the amount of peptidoglycan in the strain is below detectable amounts (Peter Schumann, personal communication).

Phospholipid fatty acid (PLFA) analysis was performed on cells that had been grown at $53{ }^{\circ} \mathrm{C}, \mathrm{pH}^{55}{ }^{\circ} \mathrm{C} 9.5,1.7 \mathrm{M}$ $\mathrm{NaCl}, \quad 640 \mathrm{mM} \quad \mathrm{Na}_{2} \mathrm{CO}_{3}$ and $320 \mathrm{mM} \quad \mathrm{NaHCO}_{3}$. Lyophilized cell material was extracted by using a chloroform/methanol/water solvent system (Bligh \& Dyer, 1959) with the modification of Peacock et al. (2001). The total lipid extract obtained was then fractionated into neutral lipid, glycolipid and polar lipid fractions by silicic acid column chromatography (Guckert et al., 1985). The polar lipid fraction was prepared for gas chromatography/mass spectroscopy by transesterification to fatty acid methyl esters by mild alkaline hydrolysis (Guckert et al., 1985). The resulting mixed fatty acid methyl esters and dimethylacetals (DMAs) were separated and quantified by using a Hewlett Packard 5890 series 2 gas chromatograph interfaced with a Hewlett Packard 5971 mass-selective detector. The chromatographic column was a $50 \mathrm{~m}$ non-polar column $(0.2 \mathrm{~mm}$ i.d., $0.11 \mathrm{~mm}$ film thickness). The amount of PLFA+DMA (g cells) ${ }^{-1}$ was $13.6 \mathrm{nmol}$ (g dry weight cell material) ${ }^{-1}$. PLFA composition of strain JW/NM-WN-LF ${ }^{\mathrm{T}}$ was dominated by branched-chain fatty acids (i15:0, i17:0), which formed $29 \%$ of total PLFAs. PLFA analysis also showed a unique pattern of DMAs, which were predominated by a branched-chain DMA (i17:0DMA, $27.4 \%$ of total PLFA) and an unbranched DMA (16:0DMA, 16.4\% of total PLFA). Small amounts of unsaturated PLFAs and unbranched DMAs were also present (see Supplementary Table S1, available in IJSEM Online).

The DNA G + C content of strain JW/NM-WN-LF ${ }^{\mathrm{T}}$ was determined by HPLC according to Mesbah et al. (1989) with the modification of Lee et al. (2005), using S1 nuclease and $0.3 \mathrm{M}$ sodium acetate ( $\mathrm{pH}$ 5.0). The $\mathrm{G}+\mathrm{C}$ content of genomic DNA was $40.4 \mathrm{~mol} \%$ (mean of six replicate analyses).

\section{Phylogenetic analysis}

The nearly complete 16S rRNA gene sequence for strain JW/NM-WN-LF ${ }^{T}$ was determined by Macrogen, Inc. (Seoul, Korea), and compared with all GenBank entries by BLAST search (http://www.ncbi.nlm.nih.gov/BLAST). The partial 16S rRNA gene sequence of strain JW/NM$\mathrm{WN}-\mathrm{LF}^{\mathrm{T}}$ was located in a phylogenetic cluster consisting of uncultured bacterial clones from sediments of the alkaline, hypersaline lakes of the Wadi An Natrun, Egypt (Mesbah et al., 2007). The $\mathrm{pH}$ in these sediments ranged from 9 to 11 and the $\mathrm{NaCl}$ concentration at the time of sampling was approximately $5 \mathrm{M}$. Strain JW/NM-WN-LF ${ }^{\mathrm{T}}$ was also related closely (93-95\% 16S rRNA gene sequence 
similarity) to unpublished bacterial strains isolated from the alkaline soda lakes in the Kenyan-Tanzanian Rift (Jones et al., 1998; Owenson, 1997). No effective description of these isolates exists in the literature describing the temperature range. These isolates were retrieved from mixed water-sediment samples and grown at $37{ }^{\circ} \mathrm{C}$ (Owenson, 1997). The soda lakes of the KenyanTanzanian Rift are reported to have $\mathrm{pH}$ values ranging between 10 and 12 and salinity levels greater than $2.5 \mathrm{M}$. The lakes are solar-heated; no source of geothermal heating has been reported. The three corresponding strains mentioned by Owenson (1997) were Gram-stainingvariable, anaerobic, heterotrophic rods of various sizes, able to use a variety of heterotrophic substrates including glucose, and formed acetate and isovalerate as major fermentation products. The $\mathrm{NaCl}$ range is given as $12-26 \%$ (w/v) $\mathrm{NaCl}$ and the $\mathrm{pH}$ optimum as $>9.5$. However, the strains are not presently available for comparison.

Among species with validly published names, the highest 16S rRNA gene sequence similarity levels were with members of the family Peptococcaceae, namely Desulfotomaculum geothermicum (approx. $85 \%$ similarity) and the type species Desulfotomaculum nigrificans ( $84 \%$ similarity) (Fig. 2). Strain JW/NM-WN-LF ${ }^{T}$ clearly belongs to the class 'Clostridia', but is not affiliated closely with any of the described lineages (Supplementary Fig. S2, available in IJSEM Online, shows type genus Natranaerobius gen. nov. for the proposed novel family and order in a tree with the type species of the type genera of the orders and classes in the phylum Firmicutes).

The 16S rRNA gene sequence of strain JW/NM-WN-LF was aligned with those of representatives of the class 'Clostridia' (Fig. 2). Multiple sequence alignments were created with the CLUSTAL_X program (http://bips. u-strasbg.fr/fr/Documentation/ClustalX/). Trees were constructed by using the PHYLIP software package (http:// evolution.genetics.washington.edu/phylip.html). Distances were calculated by using the Jukes-Cantor algorithm of
DNADIST, and branching order was determined via the neighbour-joining algorithm of NEIGHBOR. Each tree was a consensus of 1000 replicate trees. Strain JW/NM-WN-LF and the African rift isolates and environmental clones formed a strongly supported cluster, with similarity between gene sequences ranging from 92 to $96 \%$. Interestingly, strain JW/NM-WN-LF ${ }^{\mathrm{T}}$ was only $93 \%$ similar to uncultured clone WN-FSB-108, which was retrieved from sediment of the same lake, indicating that the genus Natranaerobius is represented by several species in the lakes that may even be members of closely related genera. The Natranaerobius cluster forms a separate lineage within the class 'Clostridia'. Additional phylogenetic analyses performed with $16 \mathrm{~S}$ rRNA gene sequences of the type genera of the Firmicutes and a different treeing method (Fitch-Margoliash) confirmed the divergence of strain JW/NM-WN-LF ${ }^{T}$ and related sequences from representatives of described families and orders of the class 'Clostridia' (Supplementary Fig. S2).

\section{Taxonomic conclusions}

Phylogenetic analysis indicates that strain JW/NM$\mathrm{WN}-\mathrm{LF}^{\mathrm{T}}$ belongs to the class 'Clostridia' of the phylum Firmicutes. Table 1 shows the phenotypic characteristics of strain JW/NM-WN-LF ${ }^{\mathrm{T}}$ and the two most closely related species with validly published names, D. geothermicum and $D$. nigrificans, belonging to the clostridial family Peptococcaceae. Similar to strain JW/NM-WN-LF ${ }^{\mathrm{T}}$, D. geothermicum has a growth temperature optimum of $53{ }^{\circ} \mathrm{C}$ (temperature range, $37-57{ }^{\circ} \mathrm{C}$ ), and also has i15:0 as a major cellular fatty acid. However, it clearly differs in its $\mathrm{NaCl}$ requirement for growth $(0.0-0.7 \mathrm{M})$ and lack of DMAs in the PLFA profile. D. geothermicum is also neutrophilic; it does not tolerate $\mathrm{pH}$ values greater than 8.5. D. nigrificans is distinguished from strain JW/NM$\mathrm{WN}-\mathrm{LF}^{\mathrm{T}}$ in that it is motile and has a different fatty acid content and different $\mathrm{NaCl}, \mathrm{pH}$ and temperature ranges and optima (Table 1).

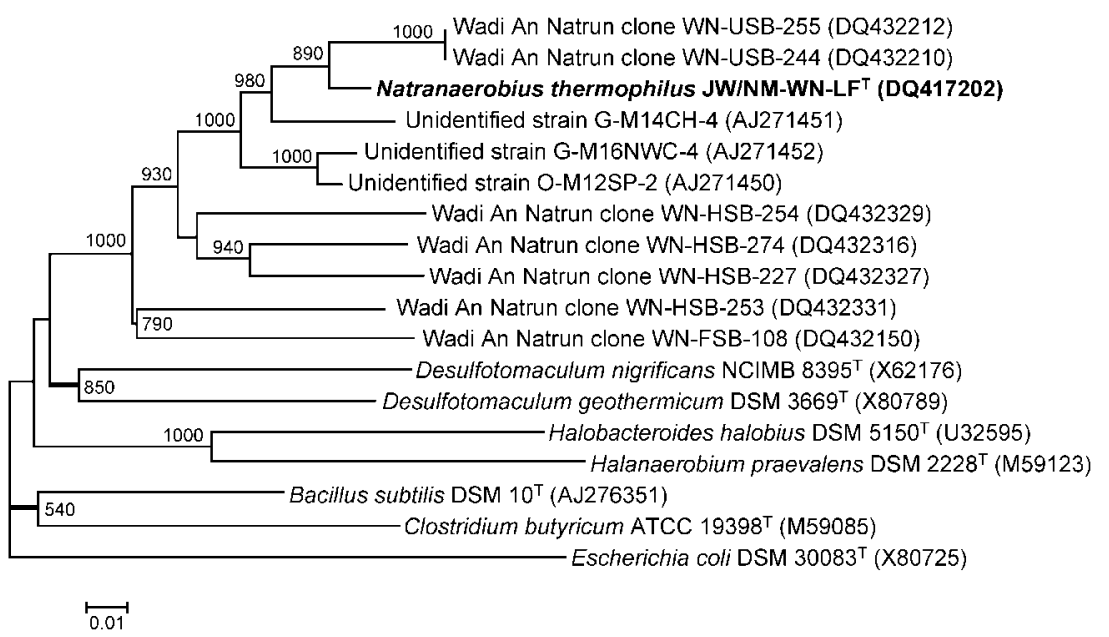

Fig. 2. Neighbour-joining tree based on $16 \mathrm{~S}$ rRNA gene sequences, showing the position of strain JW/NM-WN-LF ${ }^{\top}$ in relation to its closest relatives within the phylum Firmicutes, unidentified strains from the KenyanTanzanian Rift and uncultured clones from sediments of Wadi An Natrun lakes. GenBank accession numbers for the sequences are shown in parentheses. The tree was rooted with the 16S rRNA gene sequence of Escherichia coli DSM $30083^{\top}$ as the outgroup. Numbers at nodes are bootstrap values based on 1000 replicates; only values greater than 500 are shown. Bar, one nucleotide substitution per $100 \mathrm{nt}$. 
Table 1. Differential characteristics of strain JW/NM-WN-LF ${ }^{\top}$ and closely related species

Strains: 1, JW/NM-WN-LF ${ }^{\mathrm{T}}$; 2, Desulfotomaculum geothermicum DSM $3669^{\mathrm{T}}$ [data from Daumas et al. (1988)]; 3, Desulfotomaculum nigrificans ATCC $19998^{\mathrm{T}}$ [data from Nazina et al. (2005)]; 4, African rift isolate G-M14CH-4 (Owenson, 1997). +, Positive, -, negative; ND, not determined.

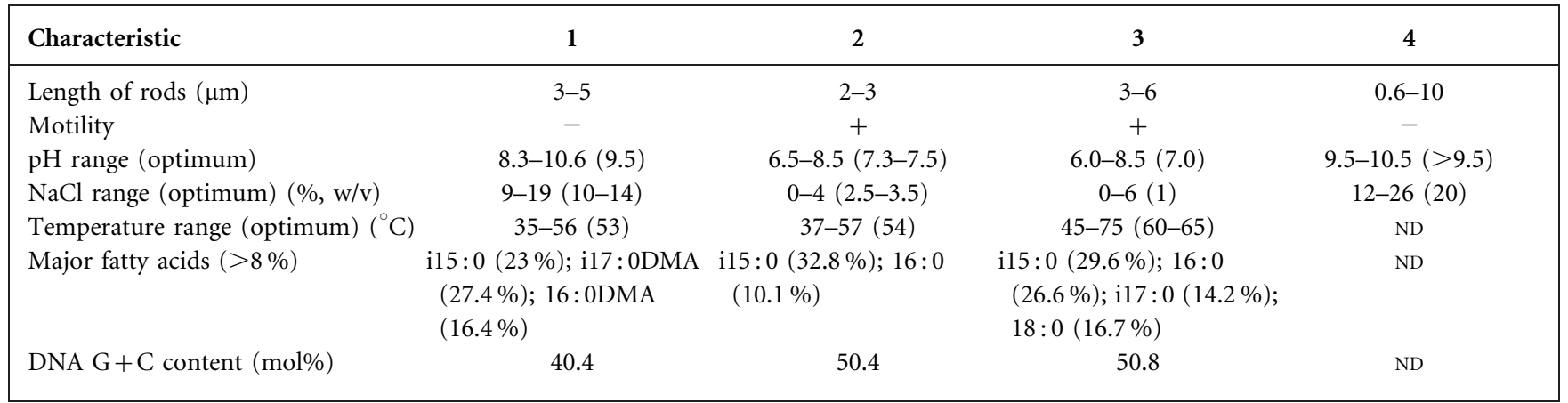

Altogether, phylogenetic and physiological data indicate that strain JW/NM-WN-LF ${ }^{\mathrm{T}}$ is sufficiently divergent from all known bacterial species to be described as a novel genus and species, Natranaerobius thermophilus gen. nov., sp. nov.

At present, the class 'Clostridia' is represented by three orders, Clostridiales, Halanaerobiales and 'Thermoanaerobacteriales'. Based on the distinct phylogenetic position of Natranaerobius thermophilus gen. nov., sp. nov. within the class 'Clostridia' and the differences observed in physiological and cultural characteristics, a novel order, Natranaerobiales ord. nov., represented by the single family Natranaerobiaceae fam. nov., is proposed.

\section{Description of Natranaerobius gen. nov.}

Natranaerobius [Natr.an.ae.ro'bi.us. N.Gr. n. natron derived from Arabic natrun soda (sodium carbonate); Gr. pref. an not; Gr. n. aer air; Gr. masc. n. bios life; N.L. masc. n. Natranaerobius a soda-requiring anaerobe].

Cells are Gram-type-positive; endospores are not observed. Obligately halophilic (growth requires at least $3 \mathrm{M} \mathrm{Na}^{+}$); obligately alkaliphilic (no growth below $\mathrm{pH} 8.3$ ). Thermophilic. Fatty acid profile is dominated by branched fatty acids with odd numbers of carbons; dimethylacetals are also present. The DNA G $+\mathrm{C}$ content is approximately $40 \mathrm{~mol} \%$. Strictly anaerobic chemo-organotrophs. The type species is Natranaerobius thermophilus sp. nov.

\section{Description of Natranaerobius thermophilus sp. nov.}

Natranaerobius thermophilus (ther.mo'phi.lus. Gr. n. therme heat; Gr. adj. philos friendly, loving; N.L. masc. adj. thermophilus heat-loving, referring to its growth temperature).

Cells form irregularly shaped to circular, opaque colonies with a white colour (when grown inside $1 \%$ agar). Cells are $3-5 \times 0.2-0.4 \mu \mathrm{m}$ in size, non-motile and catalase- and oxidase-negative. Cells are Gram-staining and Gram-typepositive (Wiegel, 1981). Extremely halophilic: optimal growth occurs between 3.3 and $3.9 \mathrm{M} \mathrm{Na}^{+}$(1.7-2.3 M added $\mathrm{NaCl}$ ); no growth occurs at $\mathrm{Na}^{+}$concentrations below $3.0 \mathrm{M}$ or greater than $5 \mathrm{M}$. Obligately alkaliphilic: $\mathrm{pH}^{55{ }^{\circ} \mathrm{C}}$ range, 8.3-10.6, with an optimum at $\mathrm{pH}^{55^{\circ} \mathrm{C}}$ 9.5. Thermophilic: temperature range for growth is $34-57{ }^{\circ} \mathrm{C}$ (at $\mathrm{pH}^{55}{ }^{\circ} \mathrm{C} 9.5$ ), with an optimum at $53{ }^{\circ} \mathrm{C}$. Obligately anaerobic. When $0.2 \%$ yeast extract and tryptone are present, fructose, cellobiose, ribose, trehalose, trimethylamine, pyruvate, Casamino acids, acetate, xylose and peptone are used as carbon and energy sources. The main organic fermentation products from $0.5 \%$ sucrose are formate and acetate. Fumarate $(20 \mathrm{mM}), \mathrm{S}_{2} \mathrm{O}_{3}^{2-}(20 \mathrm{mM})$, $\mathrm{NO}_{3}^{-}(20 \mathrm{mM})$ and iron(III) citrate $(20 \mathrm{mM})$ are utilized as electron acceptors. Major cellular fatty acids include i15:0, i17:0DMA and 16:0DMA. The type strain lacks significant amounts of murein and meso-diaminopimelic acid in the cell wall. The DNA $\mathrm{G}+\mathrm{C}$ content of genomic DNA is $40.4 \mathrm{~mol} \%$ (HPLC).

The type strain, JW/NM-WN-LF ${ }^{\mathrm{T}}\left(=\mathrm{DSM} 18059^{\mathrm{T}}=\mathrm{ATCC}\right.$ BAA- $1301^{\mathrm{T}}$ ), was isolated from sediment of Lake Fazda, Wadi An Natrun, Egypt.

\section{Description of Natranaerobiales ord. nov.}

Natranaerobiales (Natr.an.ae.ro.bi.a'les. N.L. masc. n. Natranaerobius type genus of the order; -ales ending to denote an order; N.L. fem. pl. n. Natranaerobiales the order of the genus Natranaerobius).

Description is as for the family. The type genus is Natranaerobius.

\section{Description of Natranaerobiaceae fam. nov.}

Natranaerobiaceae (Natr.an.ae.ro.bi.a'ce.ae. N.L. n. Natranaerobius type genus of the family; -aceae ending to denote a family; N.L. fem. pl. n. Natranaerobiaceae the family of the genus Natranaerobius).

Cells are Gram-staining and Gram-type-positive; endospores are not observed. Straight or slightly curved, slender rods. Non-motile. Strictly anaerobic. Members are halophilic and 
alkaliphilic. Chemolitho- or organoheterotrophic. Phylogenetically, the family belongs to the order Natranaerobiales. The type genus is Natranaerobius.

\section{Acknowledgements}

We would like to thank Sara Lee for assistance with fermentationproduct analysis, Dr Peter Schumann at the German Collection of Microorganisms and Cell Cultures for performing cell-wall analysis and Dr William B. Whitman for access to laboratory equipment. We are also grateful to Richard Davis for initial preparation of electron micrographs, Jean Euzéby for assistance with Latin nomenclature and Dr Mostafa Mesbah at the Suez Canal University, Egypt, for assistance with sampling at the Wadi An Natrun. This work was supported by grants NSF INT-021100 and NSF MCB-0604224 to J.W.

\section{References}

Baross, J. A. (1998). Do the geological and geochemical records of early earth support the prediction from global phylogenetic models of a thermophilic cenancestor? In Thermophiles: The Keys to Molecular Evolution and the Origin of Life, pp. 3-18. Edited by J. Wiegel \& M. W. Adams, Philadelphia, PA: Taylor \& Francis.

Bligh, E. G. \& Dyer, W. J. (1959). A rapid method of total lipid extraction and purification. Can J Biochem physiol 37, 911-917.

Daumas, S., Cord-Ruwisch, R. \& Garcia, J. L. (1988). Desulfotomaculum geothermicum sp. nov., a thermophilic, fatty aciddegrading, sulfate-reducing bacterium isolated with $\mathrm{H}_{2}$ from geothermal ground water. Antonie van Leeuwenhoek 54, 165-178.

Doetsch, R. N. (1981). Determinative methods of light microscopy. In Manual of Methods for General Bacteriology, pp. 21-33. Edited by P. Gerhardt, R. G. E. Murray, R. N. Costilow, E. W. Nester, W. A. Wood, N. R. Krieg \& G. B. Philips, Washington, DC: American Society for Microbiology.

Guckert, J. B., Antworth, C. P., Nichols, P. D. \& White, D. C. (1985). Phospholipid, ester-linked fatty acid profiles as reproducible assays for changes in prokaryotic community structure of estuarine sediments. FEMS Microbiol Lett 31, 147-158.

Jones, B. E., Grant, W. D., Duckworth, A. W. \& Owenson, G. G. (1998). Microbial diversity of soda lakes. Extremophiles 2, 191-200.

Kevbrin, V. V. \& Zavarzin, G. A. (1992). The effect of sulfur compounds on the growth of the halophilic homoacetic bacterium Acetohalobium arabaticum. Mikrobiologiya 61, 812-817 (in Russian).

Lee, Y. J., Wagner, I. D., Brice, M. E., Kevbrin, V. V., Mills, G. L., Romanek, C. S. \& Wiegel, J. (2005). Thermosediminibacter oceani gen. nov., sp. nov. and Thermosediminibacter litoriperuensis sp. nov., new anaerobic thermophilic bacteria isolated from Peru Margin. Extremophiles 9, 375-383.
Ljungdahl, L. \& Wiegel, J. (1986). Working with anaerobic bacteria. In Manual of Industrial Microbiology and Biotechnology, pp. 84-96. Edited by A. L. Demain \& N. A. Solomon. Washington, DC: American Society for Microbiology.

Mesbah, N. M. \& Wiegel, J. (2006). Isolation, cultivation and characterization of alkalithermophiles. Methods Microbiol, 35, 451-468.

Mesbah, M., Premachandran, U. \& Whitman, W. B. (1989). Precise measurement of the $\mathrm{G}+\mathrm{C}$ content of deoxyribonucleic acid by highperformance liquid chromatography. Int J Syst Bacteriol 39, 159-167.

Mesbah, N. M., Abou-El-Ela, S. H. \& Wiegel, J. (2007). Novel and unexpected prokaryotic diversity in water and sediments of the alkaline, hypersaline lakes of the Wadi An Natrun, Egypt. Microb Ecol (in press). doi:10.1007/s00248-006-9193-y

Nazina, T. N., Rozanova, E., Belyakova, E., Lysenko, A. M., Poltaraus, A., Tourova, T. P., Osipov, G. A. \& Belyaev, S. S. (2005). Description of Desulfotomaculum nigrificans subsp. salinus as a new species, Desulfotomaculum salinum sp. nov. Mikrobiologiia 74, 654-662 (in Russian).

Oren, A. (2000). Life at high salt concentrations. In The Prokaryotes: an Evolving Electronic Resource for the Microbiological Community, 3rd edn, release 3.7. Edited by M. Dworkin, S. Falkow, E. Rosenberg, K.-H. Schleifer \& E. Stackebrandt. New York: Springer-Verlag.

Owenson, G. G. (1997). Obligately anaerobic alkaliphiles from Kenya soda lake sediments. PhD thesis, University of Leicester, UK.

Peacock, A. D., Mullen, M. D., Ringelberg, D. B., Tyler, D. D., Hedrick, D. B., Gale, P. M. \& White, D. C. (2001). Soil microbial community responses to dairy manure or ammonium nitrate applications. Soil Biol Biochem 33, 1011-1019.

Stookey, L. L. (1970). Ferrozine - a new spectrophotometric reagent for iron. Anal Chem 42, 779-781.

Wiegel, J. (1981). Distinction between the Gram reaction and the Gram type of bacteria. Int J Syst Bacteriol 31, 88.

Wiegel, J. (1990). Temperature spans for growth: hypothesis and discussion. FEMS Microbiol Lett 75, 155-169.

Wiegel, J. (1998a). Anaerobic alkalithermophiles, a novel group of extremophiles. Extremophiles 2, 257-267.

Wiegel, J. (1998b). Lateral gene exchange, an evolutionary mechanism for extending the upper and lower temperature limits for growth of microorganisms? A hypothesis. In Thermophiles: The Keys to Molecular Evolution and the Origin of Life?, pp. 177-185. Edited by J. Wiegel \& M. W. Adams. Philadelphia, PA: Taylor \& Francis.

Wolin, E. A., Wolin, M. J. \& Wolfe, R. S. (1963). Formation of methane by bacterial extracts. J Biol Chem 238, 2882-2886.

Zavarzin, G. A. (1993). Epicontinental soda lakes are probable relict biotopes of terrestrial biota formation. Microbiology (English translation of Mikrobiologiya) 62, 473-479. 